\title{
Analisis filogenetik gen mitochondrial large subunit (mtLSU) Pneumocystis jirovecii pada Pasien Human Immunodeficiency Virus (HIV) Terduga Pneumoniae di Jakarta
}

\author{
Conny Riana Tjampakasari ${ }^{1,2}$, Andi Yasmon $^{2}$, Agus Sjahrurachman ${ }^{2}$ dan Samsuridjal Djauzi ${ }^{3}$ \\ ${ }^{1}$ Program Doktor Ilmu Biomedik, Departemen Mikrobiologi, Fakultas Kedokteran \\ Universitas Indonesia \\ ${ }^{2}$ Departemen Mikrobiologi, Fakultas Kedokteran Universitas Indonesia \\ ${ }^{3}$ Departemen Alergi Imunologi, RSCM, Fakultas Kedokteran Universitas Indonesia
}

\begin{abstract}
Abstrak
Pneumocystis jirovecii (P. jirovecii) merupakan patogen oportunistik yang penting pada pasien dengan gangguan kekebalan menurun khususnya human immunodeficiency virus (HIV). P. jirovecii tersebar dimanamana, menyebar melalui udara, dan menyerang sistem pernapasan atas. $P$. jirovecii mempunyai beberapa faktor virulensi, antara lain major surface glycoprotein $(M S G)$ yang merupakan antigen yang paling banyak ditemukan di permukaan. Pendekatan biologi molekuler digunakan untuk mempelajari patogen ini karena hingga saat ini kultur belum dapat dilakukan. Penelitian ini bertujuan untuk memperoleh data genotip yang dapat dimanfaatkan sebagai dasar data demografi dan epidemiologi molekuler $P$. jirovecii di Indonesia. Dua puluh sampel sputum positif $P$. jirovecii pada real-time polymerase chain reaction (RT-PCR) dilakukan karakterisasi terhadap gen mitochondrial large subunit ( $m t L S U$ ). Virulensi daerah hot spot gen $m t L S U$ dianalisis dengan metode PCR dan sekuensing deoxyribonucleic acid (DNA). Diperoleh 30 strain dengan 7 varian didominasi oleh varian 3 yang bersirkulasi di Jakarta. Analisis filogenetik dengan strain negara lain menunjukkan strain Jakarta berkerabat dekat dengan strain Iran, India dan Korea.
\end{abstract}

Kata kunci : Pneumocystis jirovecii, $m t L S U$, PCR, filogenetik

\begin{abstract}
Pneumocystis jirovecii (P. jirovecii) is an important opportunistic pathogen in immunocompromised patients especially human immunodeficiency virus (HIV). P. jirovecii is spread everywhere, spread through the air, and attacking the upper respiratory system. P. jirovecii has several virulence factors, including major surface glycoprotein (MSG) which is the most widely found on the surface antigen. The molecular biology approach is used to study this pathogen because until now culture cannot be done. This study aims to obtain genotype data that can be used as a basis for demographic and molecular epidemiological data of $P$. jirovecii in Indonesia. Twenty P. jirovecii positive sputum samples on real-time polymerase chain reaction (RT-PCR) were characterized by the mitochondrial large subunit ( $m t L S U$ ) gene. Virulence of the mtLSU gene hot spot region was analyzed by PCR method and deoxyribonucleic acid (DNA) sequencing. Obtained 30 strains with 7 variants dominated by variant 3 circulating in Jakarta. Phylogenetic analyzed with strains of other countries shows that Jakarta strains are closely related to strains of Iran, India dan Korea.
\end{abstract}

Keywords: Pneumocystis jirovecii, $m t L S U, P C R$, phylogenetic

\section{Pendahuluan}

Genus Pneumocystis diklasifikasi-kan sebagai jamur dalam filum Ascomycota. Jamur ini memiliki beberapa nama sesuai dengan pejamu alaminya yaitu, Pneumocystis murina pada mencit, Pneumocystis orycotolagi pada kelinci, Pneumocystis carinii dan Pneumocystis wakefieldiae pada tikus serta Pneumocystis carinii $f$. $s p$ (formae/form speciales) hominis pada manusia. ${ }^{1}$

$P$. jirovecii tersebar dimana-mana, menyebar melalui udara, menyerang sistem pernapasan atas, terdeposit di alveoli, menempel pada sel alveolar tipe 1, dan mencetus respon inflamasi pejamu. ${ }^{2}$ Pada pejamu dengan sistem imun kompeten, mikroorganisme dikeluarkan 
melalui batuk, sebaliknya jika pejamu memiliki sistem imun yang lemah, Pneumocystis dapat masuk ke alveoli dan perlahan menyebabkan kerusakan alveoli. ${ }^{3}$ Kerusakan membran kapiler alveoli dan abnormalitas perfusi pernapasan menyebabkan sindrom pernapasan akut. ${ }^{4}$

$P$. jirovecii mempunyai beberapa faktor virulensi, antara lain major surface glycoprotein (MSG) atau glikoprotein A (gpA), yang merupakan antigen yang paling banyak ditemukan di permukaan. Antigen ini merupakan protein yang pertama kali kontak dengan sel pejamu. ${ }^{5}$ Faktor virulensi berikutnya adalah dinding sel jamur berupa $\beta-(1-3)$ glukan yang berfungsi sebagai struktur sel dan merangsang respon inflamasi.

Gen lain yang berperan dalam virulensi adalah mitochondrial large subunit (mtLSU) yang berguna pula untuk studi epidemiologi molekuler. ${ }^{6}$ Perubahan posisi nukleotida pada daerah hot spot gen $m t L S U$ telah dilaporkan pada beberapa negara. Beberapa peneliti juga telah melaporkan hubungan antara variasi gen $m t L S U$ dengan keparahan penyakit. ${ }^{5,7,8}$

Saat ini diagnosis $P$. jirovecii dapat dilakukan melalui beberapa cara yaitu, pemeriksaan radiografi dan pemeriksaan mikrobiologi. ${ }^{9,10}$ Kelemahan dari pemeriksaan radiografi antara lain, tidak spesifik terhadap $P$. jirovecii karena tampilan hasil radiografi tidak berbeda dengan patogen lain. ${ }^{9}$ Untuk pemeriksaan mikrobiologi terdapat beberapa metode yang digunakan, diantaranya adalah mikroskopik, kultur, serologi, dan pendekatan secara molekuler. ${ }^{11,12}$

Sampai saat ini diagnosis jamur ini mengandalkan pada pemeriksaan mikroskopik. Kelemahan dari pemeriksaan ini antara lain tidak mudah diinterpretasikan dan memiliki nilai prediktif negatif yang tinggi. ${ }^{13,14}$ Sementara itu pemeriksaan kultur hingga saat ini masih dalam tahap penelitian, seperti yang dikembangkan oleh Verena et al (2014). ${ }^{15}$

Metode pemeriksaan lain yang telah dikembangkan lebih dari 2 dekade adalah diagnosis molekular yang berguna untuk mendeteksi dan melakukan karakterisasi deoxyribonucleic acid (DNA). ${ }^{16} \quad \mathrm{Uji}$ molekuler yang telah dilaporkan adalah uji polymerase chain reaction (PCR) dan sekuensing DNA. Metode ini selain digunakan untuk mengkarakterisasi DNA dikembangkan pula untuk mengidentifikasi pola mutasi yang dikaitkan dengan filogenetik. Tujuan dari penelitian ini adalah untuk memperoleh polimorfisme gen $m t L S U$ P. jirovecii pada pasien human immunodeficiency virus (HIV) terduga pneumonia melalui pendekatan secara molekuler yang dapat dimanfaatkan sebagai dasar data demografi dan epidemiologi molekuler $P$. jirovecii di Indonesia.

\section{Metode}

Analisis polimorfisme gen $m t L S U P$. jirovecii dilakukan pada 20 sampel sputum pasien HIV dengan pneumonia yang telah teridentifikasi gen $M S G P$. jirovecii dengan metode real-time PCR (RT-PCR). Sputum diperoleh dari pasien rawat inap dan rawat jalan pada dua rumah sakit di Jakarta. Penelitian dilakukan di Laboratorium Mikrobiologi Fakultas Kedokteran Universitas Indonesia (FKUI) Jakarta dan Lembaga Biologi Molekuler Eijkman, Jakarta pada tahun 2016-2018.

\section{Analisis polimorfisme daerah hot spot gen $m t L S U P$. jirovecii}

Polimorfisme daerah hot spot gen $m t L S U P$. jirovecii yang dianalisis adalah dari posisi nukleotida 35 sampai 241 (205 bp), sebagaimana telah dilaporkan oleh peneliti sebelumnya. ${ }^{7,16}$ Analisis ini dilakukan menggunakan metode PCR dan DNA sekuensing. Amplifikasi dilakukan menggunakan primer pAZ102-H dan pAZ102-E dan dilanjutkan sepasang primer pAZ102-X dan pAZ102-Y 
(Biotech). ${ }^{16}$ (Tabel 1). Fragmen DNA kemudian disekuensing menggunakan metode Dye Terminator dengan elektroforesis kapiler.

Tabel 1. Oligonukleotida primer yang digunakan untuk amplifikasi $P$. jirovecii ${ }^{7,16}$ (analisis genotipe gen $m t L S U$ )

\begin{tabular}{llll}
\hline Primer & Sekuen & $\begin{array}{l}\text { Target } \\
\text { gen }\end{array}$ & $\begin{array}{l}\text { Panjang } \\
\text { produk }\end{array}$ \\
\hline pAZ102-E (forward) & 5'-GATGGCT GTTTCCAAGCCCA-3' & mtLSU rRNA & $346 \mathrm{pb}$ \\
pAZ102-H (reverse) & 5'-GTGTACGTTGCAAAGTACTC-3' & & \\
pAZ102-X (forward) & 5'-TGAAATACAAATCGGACTAGG-3' & & $251 \mathrm{pb}$ \\
pAZ102-Y (reverse) & 5'-TCACTTAATATTAATTGGGGAGC-3' & & \\
\hline
\end{tabular}

\section{Nested PCR berdasarkan gen mtLSU}

Ada 3 tahap amplifikasi yang dilakukan dengan menggunakan 2 pasang primer. Tahap pertama (PCR I) dengan komposisi reaksi sebagai berikut: 1x PCR buffer HotStar, $25 \mathrm{mM} \mathrm{MgCl}, 10 \mathrm{mM}$ $\mathrm{dNTP}, \quad 1 \mathrm{x}$ Solution, 0,5 $\mu \mathrm{M}$ Primer pAZ102E, 0,8 $\mu \mathrm{M}$ Primer pAZ102H, 250U HotStar DNA Polymerase (Qiagen), dan $5 \mu \mathrm{L}$ cetakan DNA. Kondisi reaksi $95^{\circ} \mathrm{C}-15$ menit diamplifikasi 40 siklus, $94^{\circ} \mathrm{C}-30$ detik; $52^{\circ} \mathrm{C}-1$ menit; $72^{\circ} \mathrm{C}-1$ menit dan diakhiri pada $72^{\circ} \mathrm{C}-10$ menit. Hasil amplifikasi ini digunakan sebagai DNA cetakan untuk PCR II.

Tahap kedua (PCR II) dilakukan dengan komposisi reaksi sebagai berikut: 1x PCR buffer HotStar, $25 \mathrm{mM} \mathrm{MgCl} 2,10$ $\mathrm{mM}$ dNTP, 1x Solution, 0,5 $\mu \mathrm{M}$ Primer pAZ102X, 0,5 $\mu \mathrm{M}$ Primer pAZ102Y, 250U HotStar DNA Polymerase (Qiagen) dan $3 \mu \mathrm{L}$ cetakan DNA dari produk PCR I. Kondisi reaksi PCR II adalah sebgai berikut : pada $95^{\circ} \mathrm{C}-15$ menit diamplifikasi 42 siklus pada $94^{\circ} \mathrm{C}-30$ detik, $55^{\circ} \mathrm{C}-1$ menit; $72^{\circ} \mathrm{C}-1$ menit dan diakhiri pada $72^{\circ} \mathrm{C}-10$ menit.

\section{Elektroforesis dan Purifikasi}

Hasil amplifikasi PCR dianalisis pada jel agarose 2\%. Purifikasi DNA dilakukan menggunakan PCR purification kit (Qiagen). Setelah proses purifikasi selesai, DNA murni dianalisis pada jel agarose
3,5\%. Marker yang digunakan untuk elektroforesis adalah marker $100 \mathrm{pb}$ (Thermo Scientific). Pita DNA pada jel agarose selanjutnya di dideteksi menggunakan reader electrophoresis (Bio Rad) yang tersambung dengan komputer kemudian didokumentasikan.

\section{Sekuensing DNA}

Sekuensing DNA dilakukan dengan menggunakan 2 primer yang saling overlap (overlapping primers), yaitu pAZ102-X dan pAZ102-Y (Biotech). Primer dicampur dengan sekuensing reaction kit (Qiagen). Selanjutnya dimasukkan ke dalam mesin sekuenser 3130 Genetic Analyzer Applied Biosystem. Metode pembacaan basa dilakukan langsung secara otomatis menggunakan program piranti lunak sekuenser.

\section{Analisis bioinformatika}

Hasil sekuensing DNA dianalisis pada GenBank dengan metode basic local alignment searching tool (BLAST). Untuk analisis polimorfisme daerah hot spot gen mtLSU, sekuensing yang dilakukan menggunakan 2 primer yang saling overlap (overlapping DNA sequencing). Hasil overlapping DNA sequencing dianalisis menggunakan SeqScape V2.7 (Applied Biosystems).

Filogenetik dianalisis dengan metode neighbor-joining menggunakan software Molecular Evolutionary Genetics 
Analysis (MEGA) 6.0. Analisis filogenetik antar negara ditelusuri pada database GenBank yang diperoleh dari National Center for Biotechnology International (NCBI).

\section{Hasil}

\section{Polymerase chain reaction (PCR)}

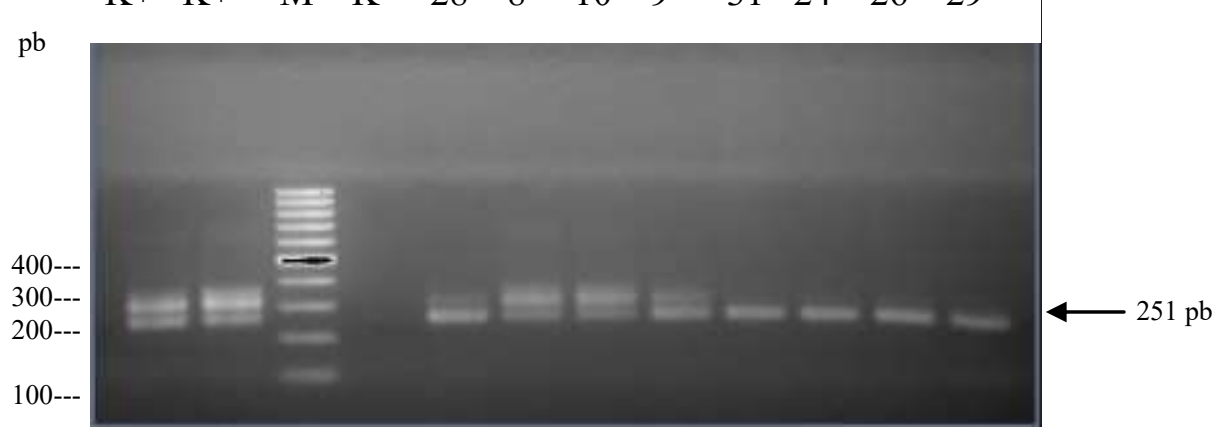

Gambar 1. Visualisasi hasil amplifikasi gen $m t L S U$. Lajur $\mathrm{K}+$ : Kontrol positif. Lajur K-:

Amplifikasi dilakukan dengan uji nested PCR terhadap gen $m t L S U$. Produk akhir amplifikasi divisualisasi pada jel agarose $2 \%$ dengan menggunakan marker 100 pb. Pada Gambar 1 dapat dilihat contoh visualisasi pita gen $m t L S U$ yang terletak pada $251 \mathrm{pb}$.

\section{Kontrol negatif. Lajur M : Marker DNA 100 pb. Lajur 28, 8, 10, 9, 24, 26, 29 : Nomor identitas pasien. \\ Purifikasi \\ Sebelum dilakukan DNA sekuensing fragmen $m t L S U 251 \mathrm{pb}$ \\ dipurifikasi menggunakan jel elektroforesis. Contoh hasil purifikasi gen $m t L S U$ dapat dilihat pada Gambar 2.}
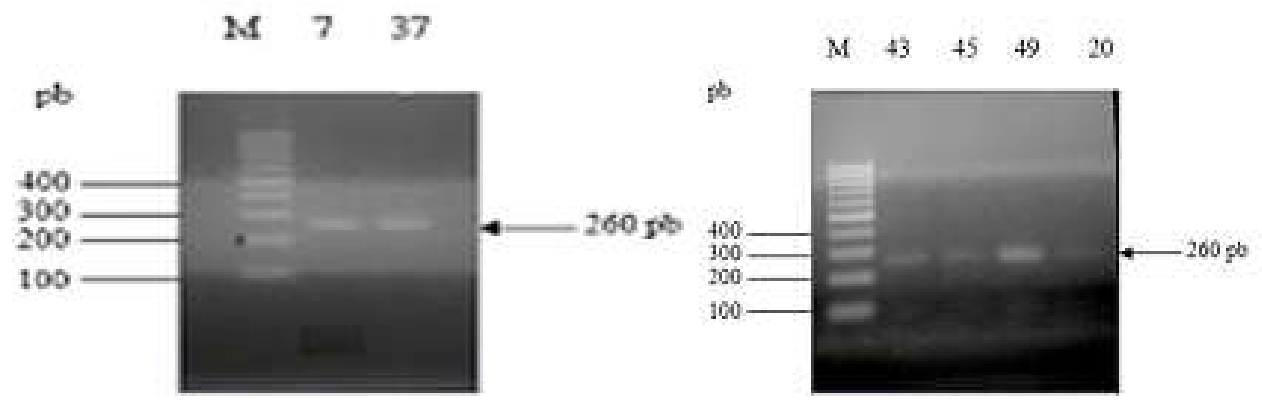

Gambar 2. Visualisasi hasil purifikasi gen $m t L S U$. Lajur M : Marker DNA 100 pb. Lajur 7, 37, 43, 45, 49, 20 : Nomor identitas pasien.

\section{Sekuensing DNA}

Hasil overlapping sekuensing DNA dianalisis menggunakan SeqScape V2.7 (Applied Biosystems). Tujuan overlapping sekuensing DNA adalah untuk saling mengkonfirmasi mutasi DNA oleh kedua primer. Sekuen DNA dinyatakan mutasi, 
jika ada kesesuaian antara hasil sekuensing oleh kedua primer.

Berdasarkan hasil sekuensing DNA, total polimorfisme gen daerah hot spot gen $m t L S U$ yang dianalisis adalah dari posisi nukleotida 35 sampai 241 (205 pb).
Variasi nukleotida gen $m t L S U$

Berdasarkan hasil analisis diketahui bahwa dari 20 pasien diperoleh 7 tipe variasi dengan 30 strain $P$. jirovecii, dimana beberapa pasien terinfeksi oleh 2 strain yang berbeda (Tabel 2).

Tabel 2. Variasi nukleotida pada daerah hot spot (205 pb [posisi nukleotida 35-241]) gen $m t L S U$ P. jirovecii

\begin{tabular}{|c|c|c|c|c|c|c|}
\hline \multirow{2}{*}{$\begin{array}{c}\text { Tipe } \\
\text { Variasi }\end{array}$} & \multicolumn{5}{|c|}{ Posisi Nukleotida } & \multirow{2}{*}{$\begin{array}{l}\text { Jumlah } \\
\text { Strain }\end{array}$} \\
\hline & 49 & 85 & 100 & 119 & 203 & \\
\hline $1 *$ & $\mathrm{C}$ & $\mathrm{C}$ & $\mathrm{T}$ & G & $\mathrm{A}$ & 8 \\
\hline 2 & $\bullet$ & $\mathrm{T}$ & $\bullet$ & $\bullet$ & $\bullet$ & 2 \\
\hline 3 & $\bullet$ & $\mathrm{A}$ & $\bullet$ & $\bullet$ & $\bullet$ & 16 \\
\hline 4 & $\mathrm{~T}$ & A & • & - & - & 1 \\
\hline 5 & $\bullet$ & A & • & A & - & 1 \\
\hline 6 & $\bullet$ & A & $\mathrm{C}$ & $\bullet$ & $\bullet$ & 1 \\
\hline 7 & $\bullet$ & $\mathrm{A}$ & $\bullet$ & • & G & 1 \\
\hline
\end{tabular}

Variasi nukleotida strain $P$. jorovecii Jakarta menunjukkan tipe variasi 3 merupakan merupakan tipe variasi nukleotida yang paling banyak ditemukan yaitu sebanyak 16 strain, tipe variasi lainnya diperlihatkan pada Tabel 3.

Tabel 3. Variasi nukleotida berdasarkan strain P. jorovecii Jakarta

\begin{tabular}{|c|c|}
\hline $\begin{array}{c}\text { Tipe } \\
\text { variasi }\end{array}$ & Strain $P$. jorovecii Jakarta \\
\hline 1 & $\begin{array}{l}\text { PJ-JKT06，РJ-JKT08B，РJ-JKT09B，PJ-JKT10B，PJ-JKT29A，РJ-JKT34B， } \\
\text { PJ-JKT37B，РJ-JKT31B }\end{array}$ \\
\hline 2 & РJ-JKT07, РJ-JKT9B \\
\hline 3 & $\begin{array}{l}\text { PJ-JKT08A，PJ-JKT09A，PJ-JKT10A，PJ-JKT20，РJ-JKT24，РJ-JKT26，РJ- } \\
\text { JKT34A，PJ-JKT43A，PJ-JKT37A，PJ-JKT45B，PJ-JKT49，РJ-JKT44B，PJ- } \\
\text { JKT31A，PJ-JKT41，PJ-JKT47，PJ-JKT48 }\end{array}$ \\
\hline 4 & PJ-JKT28 \\
\hline 5 & PJ-JKT45A \\
\hline 6 & PJ-JKT44A \\
\hline 7 & PJ-JKT43B \\
\hline
\end{tabular}


Hasil penelitian menunjukkan dari 30 strain yang dideteksi (Tabel 2), mutasi pada posisi nukleotida $49 \quad(\mathrm{C} \rightarrow \mathrm{T})$ ditemukan pada 1 strain. Mutasi pada posisi nukleotida $85(\mathrm{C} \rightarrow \mathrm{T})$ ditemukan pada 2 strain, sedangkan mutasi dari $\mathrm{C}$ menjadi A ditemukan pada 20 strain. Mutasi pada posisi nukleotida $100(\mathrm{~T} \rightarrow \mathrm{C})$, $119(\mathrm{G} \rightarrow \mathrm{A})$, dan $203(\mathrm{~A} \rightarrow \mathrm{G})$ masingmasing juga ditemukan pada 1 strain.

Kekerabatan semua strain yang ditemukan pada penelitian ini dianalisis dengan metode titik hitam nenunjukkan tidak terjadi mutasi neighbor-joining menggunakan software MEGA 6.0. Kladogram hasil analisis filogenetik membentuk 2 clade dengan 7 varian. Clade 1 terdiri dari varian 1 dan 2 sedangkan clade 2 terdiri dari 3, 4, 5, 6 dan 7. Varian 1 berkerabat dekat dengan varian 2 sedangkan varian 3 berkerabat dekat dengan varian 4, 5, 6 dan 7 (Gambar $3)$.

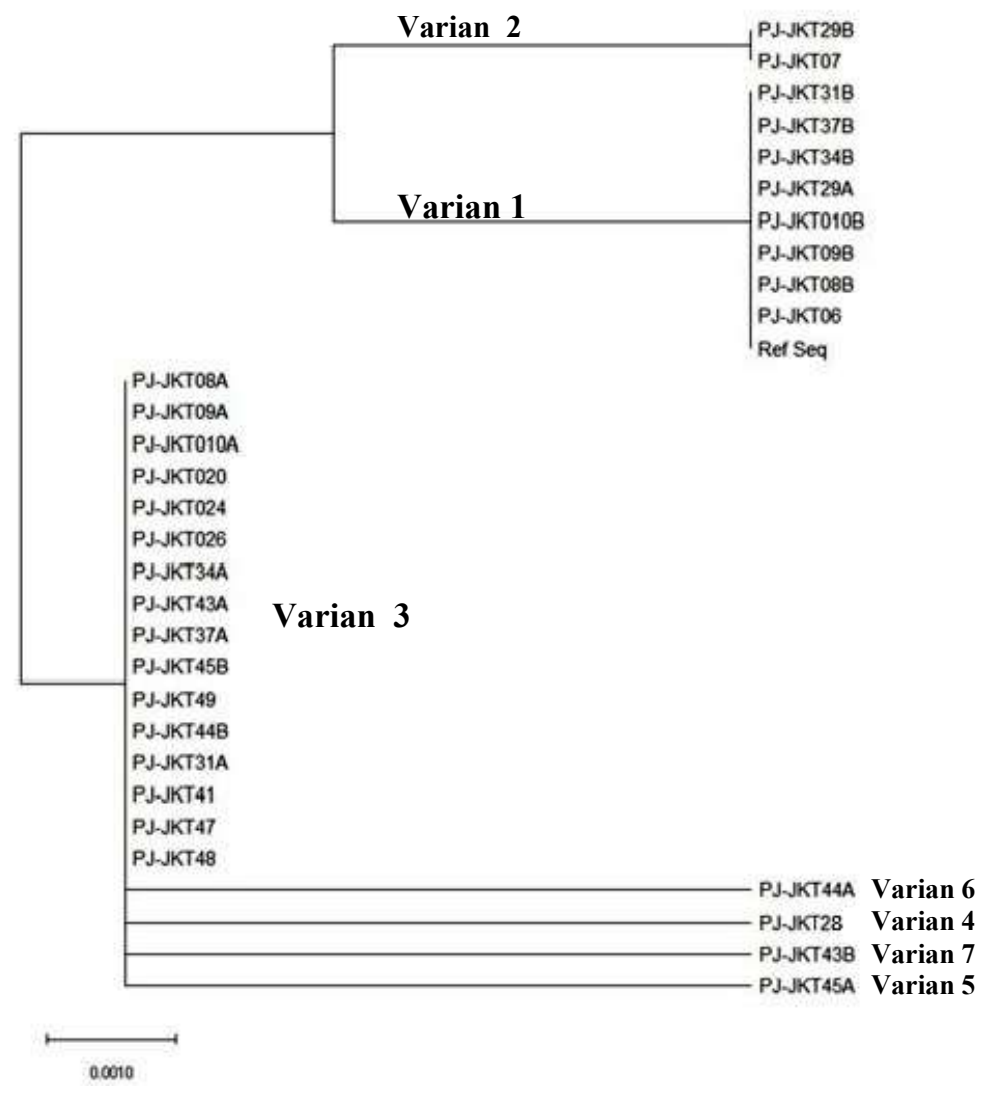

Gambar 3. Analisis filogenetik gen $m t L S U$ P. jirovecii (PJ-JKT adalah kode $P$. jirovecii strain Jakarta). 


\section{Kekerabatan strain Jakarta dengan strain negara lain}

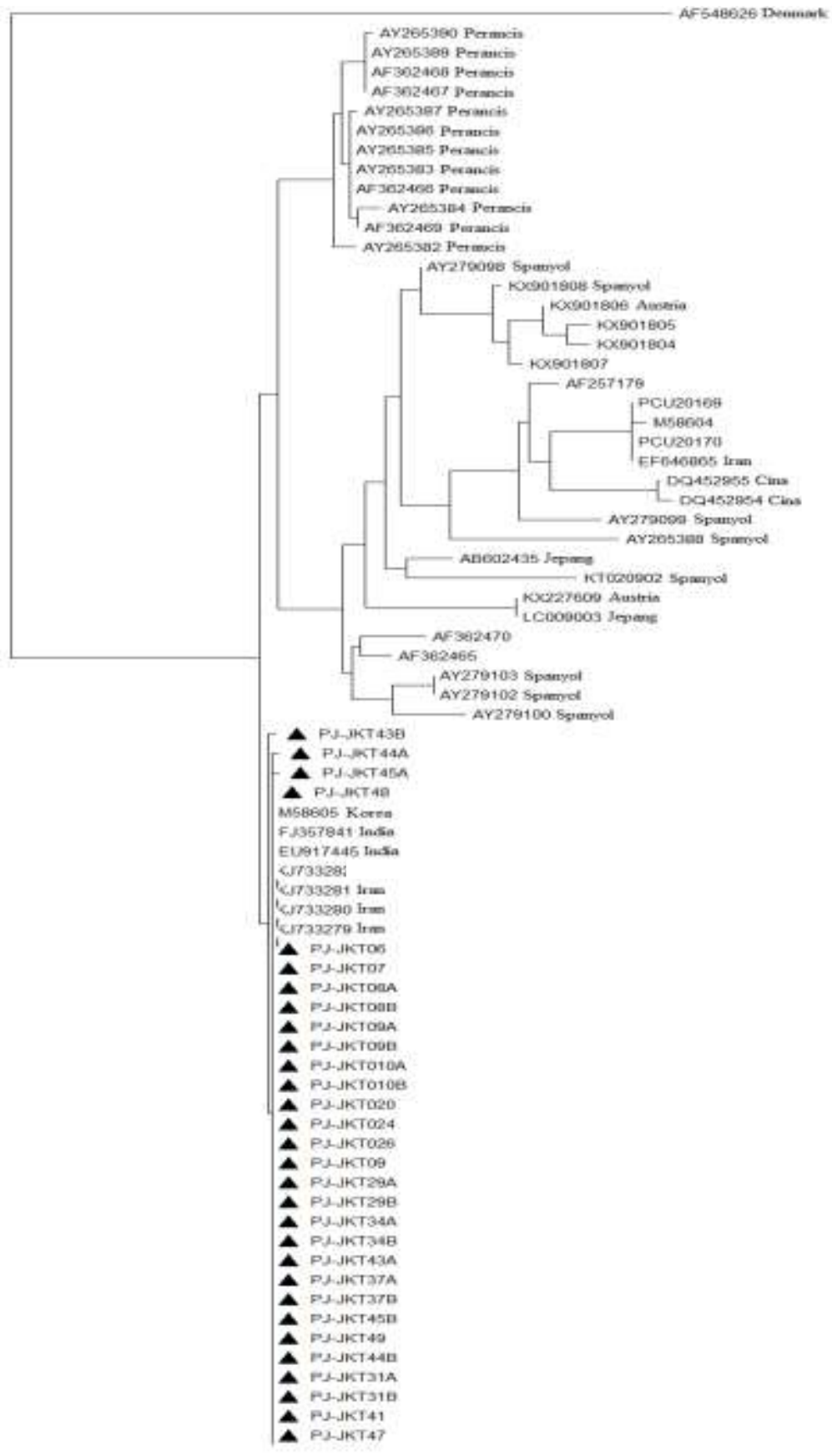

Gambar 4. Analisis filogenetik gen $m t L S U$ P. jirovecii antar negara (PJ-JKT adalah kode $P$. jirovecii strain Jakarta).

Kekerabatan strain Jakarta dengan strain negara lain dianalisis berdasarkan gen bank pada NCBI. Kladogram membentuk 2 clade. Clade pertama diisolasi dari primata non-manusia (Macaca fascicularis) sedangkan strain Jakarta berada pada clade lainnya (Gambar 4). 


\section{Pembahasan}

Pada penelitian ini, terdapat 20 subjek uji real-time PCR positif seluruhnya berhasil diamplifikasi menggunakan primer yang spesifik terhadap gen $m t L S U$. Hasil amplifikasi dilanjutkan dengan purifikasi untuk meningkatkan kemurnian DNA yang diperoleh dari hasil amplifikasi.

Konsentrasi dan kualitas DNA menjadi faktor penting penentu keberhasilan amplifikasi. Selain itu, temperatur annealing dari kedua primer, ukuran dan komposisi primer sangat penting dalam proses penempelan primer terhadap untaian DNA target. Konsentrasi $\mathrm{MgCl}_{2}$, aktivitas enzim, kualitas dan konsentrasi primer, ketepatan konsentrasi deoksinukleotida trifosfat (dNTP) serta kualitas dan konsentrasi larutan penyangga perlu diperhatikan secara cermat. Purifikasi terhadap amplifikasi gen $m t L S U$ dilakukan untuk menghilangkan beberapa kontaminan seperti senyawa sekunder (fenol), polisakarida, RNA dan juga protein sehingga hasil amplifikasi menghasilkan DNA yang bener-benar murni.

Keragaman genetik Pneumocystis pada manusia pertama kali di observasi pada gen $m t L S U$ rRNA berdasarkan polimorfisme 3 nukleotida. Perbedaan sekuen tersebut kemudian diidentifikasi berdasarkan posisi nukleotida. Sejak saat itu, gen $m t L S U$ rRNA dijadikan studi berbagai variasi genomik dan taksonomi yang berhubungan dengan jamur ini. ${ }^{17,18}$

Gen $m t L S U$ rRNA merupakan gen yang paling sering digunakan untuk target diagnosis dan kuantifikasi $P$. jirovecii. Gen ini dapat digunakan untuk penelitian epidemiologi, determinasi dan struktur genetik populasi karena memiliki derajat tinggi untuk konservasi genetik dan berguna untuk mendeteksi perbedaan intraspesifik pada populasi. ${ }^{19,20,21}$

Analisis polimorfisme pada daerah hot spot gen $m t L S U$ posisi nukleotida 35 sampai $241(205 \mathrm{pb})$ diperoleh 20 pasien dengan 30 strain $P$. jirovecii, dimana beberapa pasien terinfeksi oleh 2 strain yang berbeda (mix infections). Tujuh varian ditemukan pada penelitian ini dan tipe variasi ke-3 merupakan tipe variasi nukleotida yang banyak ditemukan yaitu sebanyak 16 strain, tipe variasi ke-2 yaitu 2 strain dan 1 strain untuk masing-masing tipe variasi nukleotida ke-4, ke-5, ke-6 dan ke-7. Dari 30 strain yang dideteksi mutasi pada posisi nukleotida $49 \quad(\mathrm{C} \rightarrow \mathrm{T})$ ditemukan pada 1 strain. Mutasi pada posisi nukleotida $85(\mathrm{C} \rightarrow \mathrm{T})$ ditemukan pada 2 strain, sedangkan mutasi dari $\mathrm{C}$ menjadi A ditemukan pada 20 strain. Mutasi pada posisi nukleotida $100(\mathrm{~T} \rightarrow \mathrm{C})$, $119(\mathrm{G} \rightarrow \mathrm{A})$, dan $203(\mathrm{~A} \rightarrow \mathrm{G})$ masingmasing juga ditemukan pada 1 strain. Sejauh ini 7 varian yang ditemukan pada penelitian ini dan belum pernah dilaporkan oleh peneliti lain.

Hasil penelitian ini berbeda dengan hasil penelitian Ernesto et al (2014) di Cuba, mereka menemukan 10 varian dengan polimorfisme dari posisi nukleotida 25 sampai 258 dengan perubahan dari $(\mathrm{A} \rightarrow \mathrm{T})$ pada posisi 25,252 dan 258. Tipe variasi ke-1, sesuai dengan gen bank dengan nomor akses GF733749 merupakan tipe variasi nukleotida yang banyak ditemukan yaitu sebanyak 31 strain. Perbedaan variasi nukleotida antara penelitian ini dan Ernesto et al (2014) antara lain dipengaruhi oleh perbedaan penyakit, spesimen dan subjek yang diteliti, transmisi dan sirkulasi genotipe $P$. jirovecii yang berbeda serta lokasi geografik. Ernesto et al (2014) meneliti bayi dan balita dengan gejala batuk sebagai subjek penelitian dengan usap nasofaring sebagai spesimen yang diteliti.

Kekerabatan strain Jakarta dengan strain negara lain menunjukkan strain yang paling dekat kekerabatannya dengan strain Jakarta adalah strain dari negara Iran, India dan Korea. Strain yang berkerabat dekat tersebut diisolasi dari pasien-pasien yang mengalami gangguan saluran pernapasan sedangkan kelompok yang berkerabat jauh diisolasi dari berbagai spesies seperti 
primata non-manusia dan berbagai rodensia.

\section{Kesimpulan}

Kladogram hasil analisis filogenetik gen $m t L S U$ P. jirovecii pada pasien HIV terduga pneumonia di Jakarta membentuk 2 clade yang didominasi oleh varian 3 . Kekerabatan strain Jakarta dengan strain negara lain menunjukkan bahwa strain Jakarta berkerabat dekat dengan strain Iran, India dan Korea.

\section{Ucapan terima kasih}

Terima kasih disampaikan kepada Pokdisus HIV-AIDS RSCM, Gedung A Ruang Perawatan RSUPN-CM dan Rumah Sakit Angkatan Laut Dr. Mintohardjo. Departemen Mikrobiologi FKUI dan Lembaga Biologi Molekuler Eijkman Jakarta.

\section{Daftar Rujukan}

1. Stringer JR, Beard CB, Miller RF, Wakefield AE. A new name (Pneumocystis jiroveci) for Pneumocystis from humans. Emerg Infect Dis. 2002;8(9):891-6.

2. Beard CB, Carter JL, Keely SP, Huang L, Pieniazek NJ, Moura INS, et al. Genetic variation in pneumocystis carinii isolates from different geographic regions: Implications for transmission. Emerg Infect Dis. 2000;6(3):26572.

3. Chinnappan J, Swaminathan S, Lakshmi PT. Sequence Based Information and Phylogenetic Analysis of Dihydrofolate Reductase in Pneumocystis. 2010;1(1).

4. Jarboui MA, Mseddi F, Sellami H, Sellami A, Makni F, Ayadi A. Genetic diversity of Pneumocystis jirovecii strains based on sequence variation of different DNA region. Med Mycol. 2013;51(6):561-7.

5. Gupta R, Mirdha BR, Guleria R, Agarwal SK, Samantaray JC, Kumar L, et al. Genotyping and phylogenetic analysis of Pneumocystis jirovecii isolates from India. Infect Genet Evol [Internet]. 2010;10(6):712-9. Available from: http://dx.doi.org/10.1016/j.meegid.2010.05.008

6. Dimonte S, Berrilli F, D'Orazi C, D'Alfonso R, Placco F, Bordi E, et al. Molecular analysis based on mtLSU-rRNA and DHPS sequences of Pneumocystis jirovecii from immunocompromised and immunocompetent patients in Italy. Infect Genet Evol [Internet].
2013;14(1):68-72. Available from: http://dx.doi.org/10.1016/j.meegid.2012.11.012

7. Monroy-Vaca EX, De Armas Y, IllnaitZaragozí MT, ToraÑo G, Diaz R, Vega D, et al. Prevalence and genotype distribution of pneumocystis jirovecii in cuban infants and toddlers with whooping cough. J Clin Microbiol. 2014;52(1):45-51.

8. Mahon C, Lehman D, Manuselis G. Textbook of diagnostic microbiology. 5th ed. USA: Saunders Elsevier; 2015. 776-85 p.

9. Ma L, Chen Z, Huang DW, Kutty G, Ishihara $\mathrm{M}$, Wang $\mathrm{H}$, et al. Genome analysis of three Pneumocystis species reveals adaptation mechanisms to life exclusively in mammalian hosts. Nat Commun [Internet]. 2016;7:1-14. Available from: http://dx.doi.org/10.1038/ncomms 10740

10. Reiss E, Shadomy HJ, Lyon GM. Fundamental Medical Mycology. Fundam Med Mycol. 2011;18(8):27710.

11. Robert-Gangneux F, Belaz S, Revest M, Tattevin P, Jouneau S, Decaux O, et al. Diagnosis of Pneumocystis jirovecii pneumonia in immunocompromised patients by real-time PCR: A 4-year prospective study. J Clin Microbiol. 2014;52(9):3370-6.

12. Riedel S, Hobden JA, Miller S, Morse SA, Mietzner TA, Detrick B, et al. Jawetz, Melnick, \& Adelberg's Medical Microbiology. 27th ed. California: Mc Graw-Hill Companies; 2016. 73-97 p.

13. Murray P, Rosenthal K, Pfaller M. Medical Microbiology. 7th ed. Philadelphia: Elsevier; 2016. 73-97 p.

14. Riana Tjampakasari C, Yasmon A, Sjahrurachman A, Djauzi S. Detection of Opportunistic Fungus Pneumocystis jirovecii Major Surface Glycoprotein (MSG) gene in HIV-AIDS Patients with Pneumoniae in Jakarta. KnE Life Sci. 2020;2020:164-76.

15. Schildgen V, Mai S, Khalfaoui S, Lüsebrink J, Pieper M, Tillmann RL, et al. Pneumocystis jirovecii can be productively cultured in differentiated CuFi-8 airway cells. MBio. 2014;5(3):1-10.

16. Vanspauwen MJ, Knops VEJ, Bruggeman CA, van Mook WNKA, Linssen CFM. Molecular epidemiology of Pneumocystis jiroveci in human immunodeficiency virus-positive and negative immunocompromised patients in the Netherlands. J Med Microbiol. 2014;63:1294302.

17. Esteves F, Montes-cano MA, De La Horra C, Costa MC, Calderón EJ, Antunes F, et al. Pneumocystis jirovecii multilocus genotyping profiles in patients from Portugal and Spain. Clin Microbiol Infect. 2008;14(4):356-62.

18. Siripattanapipong S, Worapong J, Mungthin M, Leelayoova S, Tan-Ariya P. Genotypic study of 
Pneumocystis jirovecii in human immunodeficiency virus-positive patients in Thailand. J Clin Microbiol. 2005;43(5):210410.

19. De Armas Rodríguez Y, Wissmann G, Müller AL, Pederiva MA, Brum MC, Brackmann RL, et al. Pneumocystis Jirovecii pneumonia in developing countries. Parasite. 2011;18(3):21928.

20. Rabodonirina M, Vaillant L, Taffé P, Nahimana
A, Gillibert RP, Vanhems P, et al. Pneumocystis jirovecii genotype associated with increased death rate of HIV-infected patients with pneumonia. Emerg Infect Dis. 2013;19(1):21.

21. Kim T, Lee S, Hong H, Lee JY, Kim S, Choi S, et al. Clinical characteristics of hospital-onset Pneumocystis pneumonia and genotypes of Pneumocystis jirovecii in a single tertiary centre in Korea. 2015;1-7. 